\title{
Relation of normal blood pressure with anxiety level in different individuals
}

\begin{abstract}
The heart beats and pumps the blood in the body. The blood moves all around in the body and this movement of blood drives beside the edges of blood vessels. If the blood pressure is very high, then it exert extra pressure on the arteries and may cause heart attacks and stroke. In these cases, the blood pressure increases twice than the normal blood pressure of the body. Blood pressure is affected by many factors which include body position, emotional state, breathing, sleep and exercise. Thus, it changes from persons to persons. When a person feels high level of anxiety then it becomes a medical disorder, and these anxiety levels can lead to fear, worry, apprehension, and high level of consciousness. Anxiety can be caused by some physical or emotional signs like shortness of breath or faster breathing and increased heart rate. Different people experiences different level of anxiety. Some people feel moderate level of anxiety and some feel severe level of anxiety, and it may be increased when a person going for a job interview. 123 students were participated in this study. The objective of the present study was to determine the correlation between blood pressure and anxiety level in different individuals. The females which remained happy had low diastolic blood pressure than the females which remained sad had high diastolic blood pressure. The male which remained normal had also high systolic blood pressure than the male which remained happy and sad.
\end{abstract}

Keywords: blood pressure, anxiety level

\section{Introduction}

The heart beats and pumps the blood in the body. The blood moves all around in the body and this movement of blood drives beside the edges of blood vessels. This force of pushing is called the blood pressure. Hypertension is a condition in which blood pressure of the body is very high, and hypotension is a condition in which blood pressure remains low normally. ${ }^{1-4}$ If the blood pressure is very high, then it exert extra pressure on the arteries and may causing heart attacks and stroke. In these cases, the blood pressure increases twice than the normal blood pressure of the body. Blood pressure does not remain the same during a day or night. Blood pressure is affected by many factors which include body position, emotional state, breathing, sleep and exercise. ${ }^{5-7}$ Thus, it changes from persons to persons. It is measured in mm of mercury $(\mathrm{Hg})$. This is best to check the blood pressure in relaxed or sitting state. To control blood pressure, hormones are used and these hormonal mechanisms are produced by kidney. These hormones play an important role in the regulation of blood pressure. Mostly, anxiety is often a vigorous and normal feeling. When a person feels high level of anxiety then it becomes a medical disorder, and these anxiety level can lead to fear, worry, apprehension, and high level of consciousness. Anxiety can be caused by some physical or emotional signs like shortness of breath or faster breathing and increased heart rate. Different people experiences different level of anxiety. ${ }^{8-10}$ Some people feel moderate level of anxiety and some feel severe level of anxiety, and it may be increased when a person going for a job interview. The feeling of anxiety is a portion of our body's strain response. Anxiety at the mild level can be beneficial because it helps to increase the attentiveness of a person. In moderate anxiety, the people become more nervous and unhappy. In this condition the people keeps his whole attention on a single thing and ignores everything around us. The highest level of anxiety is severe anxiety when a person feels high level of anxiety and is unable to think clearly. The objective of the present study was to determine the correlation between blood pressure and anxiety level in different individuals.

\author{
Volume 4 Issue I - 2019
}

\author{
Muhammad Imran Qadir, Ayesha Jabeen \\ Department of Molecular Biology and Biotechnology, Bahauddin \\ Zakariya University, Pakistan
}

Correspondence: Ayesha Jabeen, Department of Molecular Biology and Biotechnology, Multan, Pakistan,

Email aayshamubeen@gmail.com

Received: January 25, 2019 | Published: January 31, 2019

\section{Materials and methods}

123 students participated in this study. Sphygmomanometer is a device which is used to measure the blood pressure. To measure the blood pressure, first a cuff is located on the upper arm and expanded through a force until the movement is cut off. Stethoscope is also used for measuring the blood pressure, located over the arm. It is used to listen the sound of blood moving in the arteries. The first sound of moving blood which is listened by stethoscope is called the systolic blood pressure. When the sound diminishes then the second number shows the diastolic pressure, which is the blood pressure of heart on the break position. Thus, we measured the blood pressure of different students. A questionnaire was performed to determine the relation of normal blood pressure with anxiety level in different individuals.

\section{Statistical analysis}

Statistical study was arranged by using M-state software. $t$-Test was used to survey the consequence of every student. $p<0.05$ was dignified.

\section{Results and discussion}

The females which remained normal had high systolic blood pressure $(123 \mathrm{mmHg})$ than the females which remained happy had low systolic blood pressure $(123.7 \mathrm{mmHg})$; while the standard value of systolic blood pressure is $120 \mathrm{mmHg}$. The male which remained normal had also high systolic blood pressure $(131 \mathrm{mmHg})$ than the male which remained happy and sad. Our data was non- significant (Table 1). The females which remained happy had low diastolic blood pressure $(72.75 \mathrm{mmHg})$ than the females which remained sad had high diastolic blood $(79.73 \mathrm{mmHg}$ ); while the standard value of diastolic pressure is $80 \mathrm{mmHg}$. The male which remained happy had also low diastolic blood pressure $(76.4 \mathrm{mmHg})$ than the male which remained sad. In the case of sadness our data was significant, so high anxiety level had relation with diastolic blood pressure (Table 2). 
Table I Relation of systolic blood pressure with anxiety level

\begin{tabular}{llll}
\hline Gender & Happy & Not happy, nor sad & Sad \\
\hline Female & $123.7 \pm 17.67$ & $123 \pm 24.74$ & $121.7 \pm 1.41$ \\
Male & $128.5 \pm 2.12$ & $131.6 \pm 11.3$ & $128 \pm 11.3$ \\
Combined & $124.8 \pm 13.4$ & $125.5 \pm 18.3$ & $123 \pm 1.41$ \\
$p$-value & 0.88 & 0.5 & 0.4 \\
\hline
\end{tabular}

Table 2 Relation of diastolic blood pressure with anxiety level

\begin{tabular}{llll}
\hline Gender & Happy & Not happy, nor sad & Sad \\
\hline Female & $72.75 \pm 11.31$ & $73 \pm 11.31$ & $79.73 \pm 4.94$ \\
Male & $76.4 \pm 7.07$ & $75.1 \pm 10.6$ & $81.8 \pm 1.41$ \\
Combined & $73.69 \pm 6.36$ & $73.72 \pm 4.24$ & $80.09 \pm 6.36$ \\
$p$-value & 0.99 & 0.04 & 0.01 \\
\hline
\end{tabular}

\section{Conclusion}

The females which remained happy had low diastolic blood pressure than the females which remained sad had high diastolic blood pressure. The male which remained normal had also high systolic blood pressure than the male which remained happy and sad.

\section{Acknowledgment}

None.

\section{Conflicts of interest}

The author declares there is no conflict of interest.

\section{References}

1. Qadir MI, Malik SA. Comparison of alterations in red blood cell count and alterations in haemoglobin concentration in patients suffering from rectal carcinoma undergoing 5-fluorouracil and folic acid therapy. 2010;1(1):240-243.

2. Qadir MI, Noor A. Anemias: Rare \& Uncommon Diseases. Cambridge Scholars Publishing. 2018.

3. Qadir MI, Javid A. Awareness about Crohn's Disease in biotechnology students. Glo Adv Res J Med Medical Sci. 2018;7(3):062-064.

4. Qadir MI, Saleem A. Awareness about ischemic heart disease in university biotechnology students. Glo Adv Res J Med Medical Sci. 2018;7(3):059-061.

5. Qadir MI, Ishfaq S. Awareness about hypertension in biology students. Int J Mod Pharma Res. 2018;7(2):08-10.

6. Qadir MI, Mehwish. Awareness about psoriasis disease. Int $J$ Mod Pharma Res. 2018;7(2):17-18.

7. Qadir MI, Shahzad R. Awareness about obesity in postgraduate students of biotechnology. Int J Mod Pharma Res. 2018;7(2):14-16.

8. Qadir MI, Rizvi M. Awareness about thalassemia in post graduate students. MOJ Lymphology \& Phlebology. 2018;2(1):14-16.

9. Qadir MI, Ghalia BA. Awareness survey about colorectal cancer in students of M. Phil Biotechnology at Bahauddin Zakariya University, Multan, Pakistan. Nov Appro in Can Study. 2018.

10. Qadir MI, Saba G. Awareness about intestinal cancer in university student. Nov Appro in Can Study. 2018. 